\title{
Hinduism: Sanatana Dharma or Brahmanical Religion
}

\author{
Dr. Satendra Kumar Mishra ${ }^{1 *}$, Dr. Satyarth Prakash Tripathi ${ }^{2}$ \\ ${ }^{1}$ Assistant Professor, Amity School of Languages, Amity University, Lucknow Campus, Uttar Pradesh, India \\ ${ }^{2}$ Professor, Amity School of Languages, Amity University, Lucknow Campus, Uttar Pradesh, India
}

\begin{abstract}
DOI: $10.36348 /$ sihss.2020.v05i06.005
| Received: 03.06.2020 | Accepted: 12.06.2020 | Published: 18.06.2020
\end{abstract}

*Corresponding author: Dr. Satendra Kumar Mishra

\section{Abstract}

Religious debates today are challenging the very peace and fraternity of society just because the people who actually practice religion are often misguided by those who actually don't practice any religion. I mean the political parties and politicians. The politics round the globe has hijacked and reinterpreted the basic concepts of religion. The religion was actually established to unite the society and to guide the people to follow a particular series of morals and ideals. Today people have misunderstood Hinduism with 'Brahmanical religion'. Hinduism or Sanatana Dharma prescribes to live a simple dignified life for the service of humanity and nature. It has no definite set of rules. In the later Vedic age, the Varna system became more complex. The Brahmans created many complex set of rituals to be followed to be called a Hindu. They prescribed to follow different ways to get rid of sin and gain virtue. The Sanatana Dharma or Hinduism gradually was dominated by Brahmanical religion. It's time to look back to the roots of Hinduism and follow Sanatana dharma. If not, then at least a retrospection must be done to know the difference between Sanatana Dharma and Brahmanical religion.

Keywords: Sanatana Dharma, Hinduism, Brahmanical, Humanity.

Copyright @ 2020: This is an open-access article distributed under the terms of the Creative Commons Attribution license which permits unrestricted use, distribution, and reproduction in any medium for non-commercial use (NonCommercial, or CC-BY-NC) provided the original author and source are credited.

\section{INTRODUCTION}

The most prominent religion of India is Hinduism, which is also called 'Sanatana Dharma' due to its antiquity and vastness. Like Christianity, Islam, Buddhism, Jainism etc. Hinduism is not a religion founded by any prophet or individual, but it is a set of different traditions and beliefs that have been in existence since ancient times [1,2]. Being a developing religion, new dimensions were added to it during various periods. In fact, Hinduism is a religion with such a vast landscape that it has everything from primitive village deities, ghost-vampires, local deities, chandeliers, tantra-mantras to Tridev and other deities and formless Brahma and extremely esoteric philosophy. All without any prejudices and presumptions are worshiped irrespective to place and person. We have to move thousands of years back to Vedic age to study the traditions of Hinduism. Vedas are the root of the traditions of Hinduism. Vedic religion was nature-worshiping, polytheistic and ritualistic religion [3-6].

\section{Following are the major concepts of Hinduism}

Brahma - Brahma has been considered omnipresent, the only entity, nirgun and omnipotent. In fact, it is the 'Parabrahma' of 'Ekohum Davito Nasti' (ie there is only one, none other) of monotheism, which is Ajar, immortal, eternal and the creator of this world, rearing and welfare [7].

Aatma, Soul- Brahma is considered omnipresent, so its share is also present in the living beings. This non-existent Brahma present in the creatures is called Soul, which does not end despite the death of the creature and takes on a new body. Eventually, after attaining salvation, she merges into Brahma. The concept of rebirth is reinforced by the concept of immortality of the soul. After the death of an organism, its soul assumes a new body, that is, it is reborn. In this way, the body is only the medium of the soul [8].

'Yoni' - The organism received by each birth of a soul is called a 'Yoni'. 84 crore 'Yonis' have been conceived, including insect-moths, animals, birds, trees and humans. The 'yoni' can be called biotic species in modern scientific language [9].

'Karma Phal' - The soul has to suffer in the next life as a result of the actions performed throughout its life. Good deeds result in birth in a good 'yoni'. In 
this view, Human being is the best 'yoni'. But the ultimate goal of karma is to attain moksha i.e. the soul becomes Brahmalin.

Heaven and Hell - These are the two worlds related to Karma phal. The gods and goddesses live in heaven, while hell is extremely painful, dark, and abject. A person who does good deeds after death finds a place in heaven and evil deeds in hell.

Moksha - Moksha means - the soul's liberation from the vicious cycle of life and death, that is, getting absorbed in the Supreme. For this, it is necessary to do harmony with devotion and worship God.

Four Yugas - In Hinduism, time has been considered cyclical. In this way, four Yuga- Sata Yuga, Treta Yuga, Dvapar Yuga and Kali Yuga are considered in a period. In these four Yugas, Sata is considered the best and Kali is the worst. In these four ages, the physical and moral strength of man gradually decreases. By combining the four Yugas, a great age is formed, which has a duration of 43,20,000 years, at the end of which there is a great disaster on Earth. Then the new creation of the world begins [10].

Four Varnas - Hindu society is divided into four varnas - Brahmins, Kshatriyas, Vaishyas and Shudras. These four varnas were initially divided on the basis of karma. The duty of a Brahmin was to study, teach, worship, perform rituals. The duty of Kshatriya was to rule religiously and to fight for the defense of the country and religion. The duty of Vaishya was to fulfill the economic needs of society by agriculture and trade. The duty of Shudra was to serve the other three varnas. Over the years, the varna system became complex and it became hereditary and exploitative. The Shudras were considered untouchables. Later, other intermediate castes were born out of the physical relationships between the various varnas. Presently the caste system is visible in a very distorted form [11].

Four Ashrams - Ancient Hindu codes consider human life to be 100 years of age and divide it into four stages i.e. ashrams - Brahmacharya, Grihastha, Vanaprastha and Sannyas. The probable duration of each was assumed to be 25 years. In Brahmacharya ashram, a person goes to the Guru Ashram and gains 'Vidya', education. In the Grihastha Ashram he gets involved in marriage, childbirth, economy, charity and other social indulgence. In Vanaprastha, the person gradually assigns his worldly responsibility to his sons and eventually leaves the social life. After leaving his home in the Sannyas ashram, he becomes devoted and becomes absorbed in the worship of God.

Four Purusharthas - Dharma, Artha, Kama and Moksha. These four efforts are the desired objectives of life. Proper conduct and duty are devotion, religion is the means to earn money and to consume them properly by hard work according to your intellectual and physical ability. A person's physical enjoyment is work. Attaining freedom from life and death by practicing righteousness is salvation. Religion is the guide throughout one's life. Artha and Kama are the two main functions of Grihasta ashram and salvation is the ultimate goal of the whole life.

The Four Yogas - Jnana Yoga, Bhakti Yoga, Karma Yoga and Raja Yoga. these are the four Yogas, which are the way to connect the soul to Brahma. While Jnana Yoga follows philosophical and logical method, Bhakti Yoga follows surrender and service. Karma Yoga follows the service of the society and Raja Yoga follows physical and mental practice. These four are not contradictory, but helpful and complementary to each other.

The Char Dham - North, South, East and West. The four Hindu shrines located in the four directions are Badrinath, Rameshwaram, Jagannathpuri and Dwarka respectively. It is the sacred duty of every Hindu to visit all of them at least once in lifetime.

Major scriptures - The major texts of Hindu religion are the four Vedas (Rig Veda, Sama Veda, Yajur Veda and Atharva Veda), thirteen Upanishads, eighteen Puranas, Ramayana, Mahabharata and Gita. Apart from this, there are many folk stories, ritual texts etc. Sixteen sacred rites (Solah Sanskar) are performed from birth to death.

The diversity and multi-dimensional tendency of Hinduism is unique. In this, many philosophers tried to understand God and truth in different ways, resulting in the emergence of many philosophical views. Hinduism i.e Sanatana Dharma is the oldest religion among all religions of the world. It is a religion based on the Vedas, which contains many different worship practices, beliefs, sects and philosophies.

It is the third largest religion in the world by number of followers, most of its worshipers are in India by number and Nepal by percentage. Although many deities are worshiped in it, it is in fact a monotheistic religion. Hinduism is also called Vedic Religion. A Hindu is not only a religion or a sect, but a way of life. 'Vasanthayam Duyate or Sa Hindu' ie, one who keeps away from violence with his mind, words, deeds is a Hindu, his Karma is to serve humanity. The history of Hinduism can be traced much before the Indus Valley Civilization. Many symbols of Hinduism were unearthed from Indus valley. Among these are the statues of mother goddess, the postures of a deity like Shiva Pashupati, Linga, worship of Peepal, etc. According to a group of historians, another caste came from Central Asia during the end of Indus civilization, who called themselves Aryans. They spoke Sanskrit. According to another view, the people of Indus Valley 
Civilization were Aryans themselves and their original place was India only [12].

The Aryan civilization is called the Vedic civilization. According to the first view, the Aryans settled in Afghanistan, Kashmir, Punjab and Haryana in about 1600 BC. Since then, those people (their learned sages) started chanting mantras in Vedic Sanskrit to please their gods. The first four Vedas were composed, of which Rigveda was the first. Then there were texts like Upanishads. According to Hindu belief, the Vedas, Upanishads etc. are eternal and were transferred to Aryans by the grace of God. The different sages received knowledge of different texts, who then scripted them. After the birth of Buddhism and Jainism, there was a lot of change in Vedic religion. New gods and new philosophies emerged. This is how modern Hinduism was born. According to one view, the origin of Hinduism is probably in the Indian tradition even before the Indus-Saraswati tradition (the source of which is found in $7500 \mathrm{BC}$ culture of Mehrgarh). There is no single set of principles in Hinduism which all Hindus must follow. This is a way of life more than religion. There is no central church or religious organization of Hindus, nor any 'pope'. Many beliefs and sects fall under it, and equal reverence is given to all. The scriptures are also many. Nevertheless, the main principles that most Hindus believe in are faith in religion (global law), karma (and its fruits), the worldly cycle of rebirth, moksha (liberation from worldly bonds) - which can have many paths, And of course, God. Hinduism considers heaven and hell to be temporary. According to Hinduism, all beings in the world have a soul. Man is the only creature who can enjoy sin and virtue, both actions in this world, and can attain salvation. There are four main sects in Hinduism: Vaishnavas (who consider Vishnu as God), Shaiva (who considers Shiva as God), Shakta (who considers Goddess as the ultimate power) and Smarta (who consider different forms of God as the same Huh). But most Hindus do not classify themselves in any sect 13].

In ancient times and medieval times, Shaiva, Shakta and Vaishnava used to quarrel among themselves for supremacy. The medieval saints tried to coordinate and described all the sects as interdependent.

Who is a Hindu? - "Goshu
Bhaktibharvedyasya Pranave ch derha mati.
Punarjanmin Vishwashah sa wai Hinduriti Smritah",
That is, one who has devotion in Gomata, who enchants
mantras and believes in rebirth, is a Hindu.

According to Merutantra, episode 33, "Heenam Dushyati sa Hindu" means one who considers 'Heen' (inferiority or inferiority) to be contaminated (renounced).

$\begin{aligned} \text { According to } & \text { Lokmanya Tilak- "Asindho: } \\ \text { Sindhuparyantaisya, } & \text { Bharatbhumika. }\end{aligned}$

Punyabhschaiva sa wai Hinduriti Smritah", That is, from the point of origin of the Indus River to the Indus (Indian Ocean), the entire land of India, which is Pitrubhu (or mother land) and Punyabhu (holy land), (and its religion is Hinduism) is called Hindu.

The word Hindu is originally Arabic. The Arab traders named the land after river 'Sindhu' as 'Hindustan' and the people residing as 'Hindu'. It means those Indians who are native of the boundary of Bharatvarsha described in the ancient texts of India, Vedas and Puranas. Based on Kalika Purana, Medni Kosh, etc. According to the basic principles of Hinduism, Hindu believes in Vedic religion. Although some people consider Indian culture to be a mixed form of many cultures. Many religious historians doubt this fact. How can that religion or culture be Indian (Hindu) which has not originated and developed on the land of India?

In short, the major elements of Hinduism are the following:

1. God is one with many names.

2. 'Brahma' or Supreme Element is omnipresent.

3. Do not fear God but love and seek inspiration.

4. The goal of Hindutva is above heaven and hell.

5. There is no one prophet among Hindus.

6. God is born again and again for protection of Dharma (Moral way of living).

7. Philanthropy is virtue It is a sin to torture others.

8. Service of the living is the service of the divine.

9. Woman is respectable.

10. Sati means honesty to the husband.

11. Habitation of Hinduism is in the mind, samskaras and traditions of the Hindu.

12. High priority to protect the environment.

13. Hindutva vision is egalitarian and coordinating.

14. 'Soul' is 'Azar-Amar', Eternal.

15. The biggest mantra is the Gayatri Mantra

16. The festivals of Hindus are associated not with worship but with 'spreading happiness'.

17. The goal of Hindutva is 'Purushartha', moral way of life.

18. The Middle Way, 'Madhyam Marg' is considered the best.

19. Hindutva is the philosophy of unity.

20. Hinduism is NOT a religion bind by a religious set of rules to be followed but 'a way of life to be followed to serve humanity'.

Today people have misunderstood Hinduism with 'Brahmanical religion'. Hinduism or Sanatana Dharma prescribes to live a simple dignified life for the service of humanity and nature. It has no definite set of rules. In the later Vedic age, the Varna system became more complex. The Brahmans created many complex set of rituals to be followed to be called a Hindu. They prescribed to follow different ways to get rid of sin and gain virtue. The Sanatana Dharma or Hinduism gradually was dominated by Brahmanical religion. It's 
time to look back to the roots of Hinduism and follow Sanatana dharma. If not, then at least a retrospection must be done to know the difference between Sanatana Dharma and Brahmanical religion $[14,15]$.

\section{REFERENCES}

1. Pattanaik, D. (2014). 'Shikhandi and other tales they don't tell you', Penguin books.

2. Abd al Ati, H. (1998). 'Islam in focus', Amana publications, Maryland, USA.

3. Holy Bible, 'The Gideons International'.

4. Vedant Tirth, A. (2011). 'Rig Veda', Manoj publications, Delhi.

5. Khanna, M. (2007). 'Cultural history of medieval India', Social science press, Delhi.

6. Ramchandran, R. (2013). 'Hinduism in the context of Manusmriti, Vedas \& Bhagvadgeeta', Vitasta publication, Delhi.
7. Gandhi, M. K. (2014). 'The essence of hinduism', Farsight publications, Delhi.

8. Rajaram, K. (2014). 'Facets of Indian Culture', Spectrum's.

9. Chakravarti, S. (1991). 'Hinduism, a way of life'. Motilal Banarsidass Pub.

10. Chatterjee, S., \& Datta, D. (1984). 'An Introduction to Indian Philosophy', University of Calcutta.

11. Chopra, R. M. (2015). 'A Study of Religions', Anuradha Prakashan, New Delhi.

12. Ludden, David, E. (1996). 'Contesting the Nation: Religion, Community and the Politics of Democracy in India', Univ. of Pennsylvania.

13. Swami, P. (1997). 'Protecting secularism and federal fair play', Frontline.

14. Enroth, R. (2005). 'Guide to New Religious Movements', Inter Varsity Press.

15. 'History of Religions in India', www.indohistory.com 